\section{Effect of Copper, Zinc and Lead and Their Combinations on the Germination Capacity of Two Cereals}

\author{
Ioana Mihaela Tomulescu ${ }^{1}$ - Edith Mihaela Radoviciu ${ }^{1}$ - \\ Vasilica Viorica Merca ${ }^{2}$ - Adela Dana Tuduce ${ }^{1}$ \\ ${ }^{1}$ University of Oradea, Faculty of Science, \\ Department of Biology, Romania \\ ${ }^{2}$ University of Oradea, Faculty of Science, \\ Department of Chemistry, Romania
}

\section{SUMMARY}

The majority of researchers have studied the following group of microelements: $\mathrm{B}, \mathrm{Zn}, \mathrm{Mn}, \mathrm{Cu}, \mathrm{Na}$, Co, $\mathrm{Mo}, \mathrm{I}, \mathrm{Sn}, \mathrm{Cl}, \mathrm{Al}, \mathrm{V}, \mathrm{F}$, $\mathrm{Cr}, \mathrm{Hg}, \mathrm{Cs}, \mathrm{Li}, \mathrm{Cd}$, As, Th, Rb, Cr, W, Ti, Sn, Se, Ba, Br. Sporadically, the following elements have been mentioned too: $A u$, $\mathrm{Ra}, \mathrm{Hg}$ and $\mathrm{Pb}$. In this study, the effects of copper treatments and their combination with zinc and lead microelements on the germination of maize and barley were investigated using different concentrations of these microelements. Six treatments were used: 1. Copper-sulphate $\left(\mathrm{CuSO}_{4}\right)$ applied alone, 2. Zinc-sulphate $\left(\mathrm{ZnSO}_{4}\right)$ applied alone, 3. Copper applied with zinc, 4. Leadnitrate $\left(\mathrm{Pb}\left(\mathrm{NO}_{3}\right)_{2}\right)$ applied alone, 5. Copper applied with lead and 6. Untreated control. Maize (Kiskun SC 297) and barley caryopsis were treated with copper and zinc solutions in the following concentrations: $0.03 \%, 0.003 \%$ and $0.0003 \%$. Maize and barley caryopsis were treated with these solutions for 12 and 24 hours. Maize and barley caryopsis were also treated with lead solutions $\mathrm{Pb}\left(\mathrm{NO}_{3}\right)_{2}$ with different concentrations: $0.0005 \%, 0.005 \%$ and $0.05 \%$. Maize and barley were treated with these solutions for 12 and 24 hours. In the combined treatments (3 and 5), the same concentration was used for each microelement as in treatments 1 , 2 and 4. Control treatments were treated with water for both plant species. Our results showed that copper microelements significantly inhibit germination compared to the untreated control. The toxicity of copper is higher if concentration increases. Zinc microelements also inhibit germination, however its effect highly depends on the microelement concentration. Treatments of copper + zinc also inhibit germination. The two microelements applied together cause more phytotoxicity than they do alone. Lead is highly toxic to plants even in low concentrations. The toxic effect on germination dramatically increased when lead was applied with copper.

Keywords: copper, zinc, lead, maize, barley, germination ability, toxicity

\section{INTRODUCTION}

Research about elementary composition of plants has demonstrated that the most important 12 elements are the following: $\mathrm{C}, \mathrm{H}, \mathrm{O}, \mathrm{N}, \mathrm{S}, \mathrm{P}, \mathrm{Cl}, \mathrm{Ca}$, $\mathrm{Mg}, \mathrm{K}, \mathrm{Na}$ and Fe (Mohr and Schopfer, 1995; Trifu, 1976). More recently, studies have shown that 17 elements constantly serve in plant composition (Buchanan et al., 2000; Mehra and Farago, 1994; Mohr and Schopfer, 1995). The concentration of manganese in dry tissue is, for example, $50 \mathrm{mg} / \mathrm{kg}$ or $0,005 \%$. In some cases, the plants tissues contain $\mathrm{Mn}$ almost as much as $\mathrm{S}(0.01 \%)$ or $\mathrm{Mg}(0.2 \%)$ (Buchanan et al., 2000; Salisbury and Ross, 1992). The majority of researchers (Brooks, 1994; Epstein,
1972; Farago, 1994; Menkel and Kirkby, 1994; Ross, 1994; Scharrer, 1975; Sutcliffe and Baker, 1974) included the following elements in the group of microelements: $\mathrm{B}, \mathrm{Zn}, \mathrm{Mn}, \mathrm{Cu}, \mathrm{Na}, \mathrm{Co}, \mathrm{Mo}, \mathrm{I}, \mathrm{Sn}$, $\mathrm{Cl}, \mathrm{Al}, \mathrm{V}, \mathrm{F}, \mathrm{Cr}, \mathrm{Hg}, \mathrm{Cs}, \mathrm{Li}, \mathrm{Cd}, \mathrm{As}, \mathrm{Th}, \mathrm{Rb}, \mathrm{Cr}, \mathrm{W}$, $\mathrm{Ti}, \mathrm{Sn}, \mathrm{Se}, \mathrm{Ba}, \mathrm{Br}$. Sporadically, they mentioned as microelements the following elements, too: $\mathrm{Au}, \mathrm{Ra}$, $\mathrm{Hg}$ and $\mathrm{Pb}$.

Copper content in plants varies over a large scale. Cereals, wheat, barley and oat are more vulnerable to copper deficiency than maize and rye (Caramete et al., 1973; Ross, 1994; Salisbury and Ross, 1992; Taiz and Zeiger, 1991; Trifu and Bărbat, 1997). In maize, the content of copper in normal leaves is more than 8 ppm, and in unhealthy plants, the copper content decreases to below $6 \mathrm{ppm}$. The symptoms of copper deficiency are dark green leaves with necrosed spots (Mohr and Schopfer, 1995; Salisbury and Ross, 1992). Leaves present malformations and those which are young are permanently whithered. Vegetative development is not as affected as germinative. Development of roots decreases, and they are long, thin and white (Trifu, 1976; Trifu and Bărbat, 1997). The critical level of copper toxicity in plants is around $20-30 \mathrm{mg} / \mathrm{kg}$ dry tissue (Vangrosveldt and Clijsters, 1994). The most important symptoms of copper toxicity are chlorosis, modifications in root morphology and development, decrease of stem development and eventual, perturbation in the plant development (Bathory et al., 1997; Mehra and Farago, 1994; Ouzounidou, 1994, 1995a, 1995b; Punz and Siegardt, 1993). It can also be mentioned that copper, as a fungicide, can also cause phytotoxicity (rusetting) in several plant species (Holb and Heijne, 2001; Merrington et al., 2002; Holb et al., 2003; Stover et al., 2004).

The content of zinc in faulty plants varies by species (Caramete et al., 1973; Salisbury and Ross, 1992). The symptoms of zinc deficiency vary from species to species and are manifested by a decrease in plant development, malformations of position and morphology of leaves, and also observed were yellow colored leaves (sometimes with yellow lines). Maize is one of the plants which responds very quickly to zinc deficiency. The symptoms in maize are: chlorosis, thin lines on leaves and whithered appearance (Cakmak, 2000; Mehra and Farago, 1994; Salisbury and Ross, 1992; Trifu and Bărbat, 1997). Excess of zinc in plants is harmful, because it blocks the assimilation of iron and the plant becomes chlorotic. Zinc toxicity shows generally a deficiency in development, chlorosis, and red-brown 
pigmentation in the chlorotic area (Caramete et al., 1973; Davis and Parker, 1993; Mehra and Farago, 1994).

The factors which determine lead content in plants are: mining activities, traffic density, distance from road and climatic conditions. Roots accumulate and fix large amounts of lead. The inhibitory effects of lead on enzyme activities were studied in maize leaves. These include perturbated photosynthesis, respiration, the content of photo assimilation pigments and some important enzymes.

The aim of our study was to compare the effect of copper and its combination with zinc and lead on the germination of maize and barley.

\section{MATERIAL AND METHODS}

The effects of copper microelements and their combinations with zinc and lead on the germination of maize and barley were investigated using different concentrations of microelements. Six treatments were used:

1. Copper-sulphate $\left(\mathrm{CuSO}_{4}\right)$ applied alone,

2. Zinc-sulphate $\left(\mathrm{ZnSO}_{4}\right)$ applied alone,

3. Copper applied with zinc,

4. Lead-nitrate $\left(\mathrm{Pb}\left(\mathrm{NO}_{3}\right)_{2}\right)$ applied alone,

5. Copper applied with lead,

6. Untreated control.

Maize (Kiskun SC 297) and barley caryopsis were treated with copper and zinc solutions in the following concentrations: $0.03 \%, \quad 0.003 \%$ and $0.0003 \%$. Maize and barley caryopsis were treated with these solutions for 12 and 24 hours. Maize and barley caryopsis were also treated with lead solutions $\mathrm{Pb}\left(\mathrm{NO}_{3}\right)_{2}$ at different concentrations: $0.0005 \%$, $0.005 \%$ and $0.05 \%$. Maize and barley were treated with these solutions for 12 and 24 hours. In the combined treatments (3 and 5), the same concentration was used for each microelement as in treatments 1,2 and 4. Control treatments were treated with water for both plant species. After the treatment application, the capacity of germination was determined in percentages. All treatments were made in three replications. Significant effects of the treatments were analysed by analysis of variance.

\section{RESULTS AND DISCUSSIONS}

The capacity for germination after 12 hours of treatments decreased with increasing copper concentrations (Figure 1). This decrease was significant for copper concentrations of 0.3 and $0.03 \%$, compared to the control treatment. After 24 hour treatments, the germination capacity also decreased with an increasing copper concentration. The decrease of $0.3,0.03$ and $0.003 \%$ concentrations of copper was significant compared to the control treatment.

The capacity for germination after 12 hours of treatments decreased with increasing zinc concentrations (Figure 2). This decrease was significant for zinc concentrations of 0.0003 and $0.03 \%$, compared to the control treatments. After 24 hour treatments, germination capacity also decreased with increasing copper concentration. The decrease of 0.03 and $0.003 \%$ concentrations of zinc was significant compared to the control treatment.

The capacity for germination after 12 hours of treatments decreased with increasing copper + zinc concentrations (Figure 3). This decrease was significant at all concentrations compared to the control treatments. However, after 24 hours treatments, the decrease of germination capacity was not clear and there were no significant differences among treatments.

Figure 1: Capacity for germination after 12 and 24 hour treatments of different concentrations of copper microelement

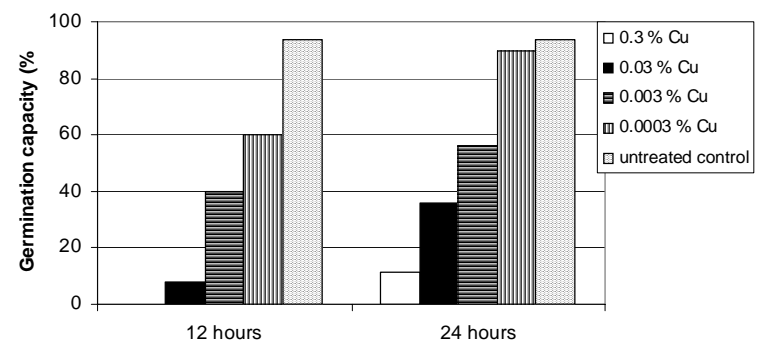

Figure 2: Capacity for germination after 12 and 24 hour treatments of different concentrations of zinc microelement

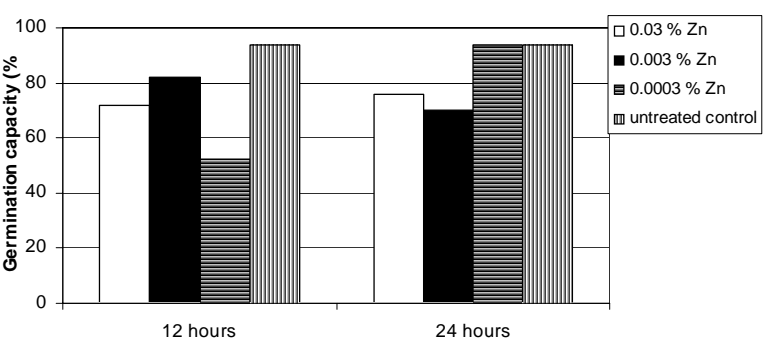

Figure 3: Capacity for germination after 12 and 24 hour treatments of different concentrations of copper + zinc microelements

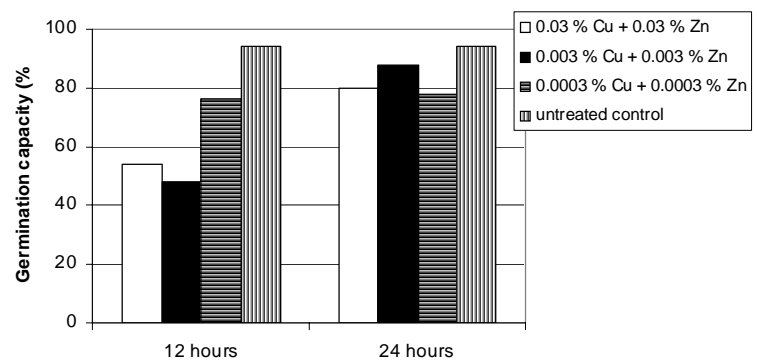

Some authors on wheat plants observed that plants grow on copper treated plots; however plant growth significantly decreased when it was compared the untreated control plots (Lanaras et al., 1993). The plants height was $25 \%$ lower on copper soils than in soils without copper treatments. These results are in agreement with other published data (Breckel, 1991; Kahle, 1993; Arduini et al., 1994; Ouzounidou, 1994, 1995a, 1995b). In contrary, zinc is very important in the vegetative organs of plants (Barman et al., 1999, 2000; Tomulescu et al., 2000b). 
The capacity for germination after 12 and 24 hours of treatment decreased with an increase in lead concentrations (Figure 4). This decrease was significant for all concentrations, compared to the control treatments.

After 12 and 24 hours of treatment, the capacity for germination dramatically decreased with an increase in copper + lead concentrations (Figure 5). The highest concentration of copper and lead mixture completely inhibited germination. This decrease was significant at all concentrations compared to the control treatments.

Figure 4: Capacity for germination after 12 and 24 hour treatments of different concentrations of lead microelement

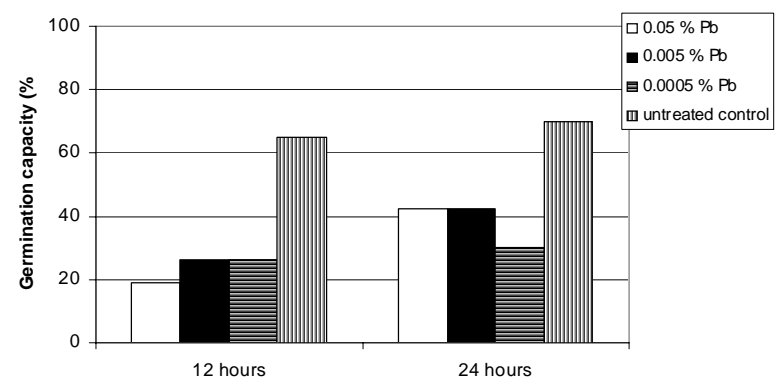

Figure 5: Capacity for germination after 12 and 24 hour treatments of different concentrations of lead + copper microelements

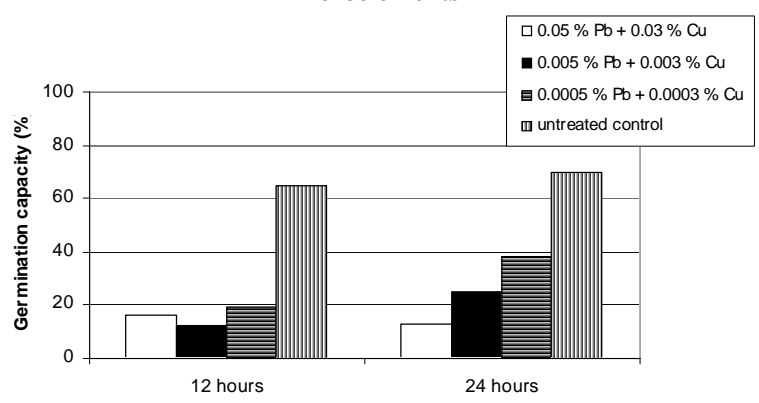

Some authors (Mehra and Farago, 1994) stated that effects determined by lead toxicity are diverse and often contradictory. It seems that lead ions penetrating the plant obstruct the enzymes and disturb the electolytic equilibrium, inhibit cell division and negatively influence plant germination and development. Our results are in agreement with previous research (Băliban et al., 1999; Tomulescu and Burcă, 2003a, 2003b; Tomulescu et al., 2003a, $2003 \mathrm{~b}$ ). In barley, lead may be more toxic to germination than copper. Our results on lead phytotoxicity are in agreement with previous research in Cladonia, Plantago and Typha (Tomulescu et al., 2000a, 2000b).

\section{CONCLUSIONS}

The following conclusions were drawn from the comparative study of the effects of copper microelements and combined zinc and lead on the germination of corn and barley.

1. Copper microelements inhibit germination significantly compared to the untreated control. The toxicity of copper is higher if concentration increases.

2. Zinc microelements also inhibit germination; however, its effect depends highly on microelement concentration.

3. Treatments of copper + zinc also inhibit germination. The two microelements applied together cause more phytotoxicity than they do alone.

4. Lead is highly toxic to plants, even in low concentrations. The toxic effect on germination dramatically increased when lead was applied with copper.

\section{REFERENCES}

Arduini, I.-Goldbold, D. L.-Onnis, A. (1994): Cadmium and copper change root growth and morphology of Pinus pinea and Pinus pinaster seedling. Physiol. Plant., 92. 675-680.

Băliban, Z.-Burcă, S.-Tomulescu, I. M.-Covaciu-Marcov, S. D. (1999): Studiu asupra cantității de acizi nucleici din diferite organe vegetative ale plantelor de cultură. Analele Universității din Oradea, Fasc. Biologie, VI. 285-294.

Barman, S. C.-Kiskun, G. C.-Bhargava, S. K. (1999): Accumulation of heavy metal in vegetables, pulse and wheat grown on flyash amended soils. J. Environ. Biol., 20. 15-18.

Barman, S. C.-Sahn, R. K.-Bhargava, S. K.-Chaterjec, C. (2000): Distribution of heavy metals in wheat, mustard and weed grown in field irrigated with industrial effluents. Bull. Environ. Contam. Toxicol., 64. 489-496.

Bathory, D.-Nicoară, A.-Bercea, V. (1997): Efectul toxic al metalelor grele asupra unor procese fiziologice la fag. Studii Cercet., Şt. Nat., (Bistrița), 3. 239-249.

Breckel, S. W. (1991): Growth under stress. Heavy metals. In (Waisel, Y.-Eshel, A.-Kafkofi, E. eds.) Plant Roots: The Hidden Half. M. Deckker, Inc.: 351-373.

Brooks, R. R. (1994): Plants and Hyperaccumulate Heavy Metals. In Plants and Chemical Elements, 88-105, Edited by Farago,
M. E., VCH, Weinheim, New York, Basel, Cambridge, Tokyo Buchanan, B. B.-Gruissen, W.-Jones, R. L. (2000): Biochemistry and Molecular Biology of Plants. Am. Soc. Plant. Physiol., Rockville, Maryland Courier Companies, Inc.: 824-1196.

Cakmak, I. (2000): Possible role of zinc protecting plant cells from damage by reactive oxygen species. New Phytol., 146. 2. 185205.

Caramete, C.-Caramete, A.-Dumitrescu, F.-Idriceanu, A.-Popescu, I.-Săndulache, R.-Stan, S.-Vineş, I. (1973): Nutriția plantelor şi aplicarea îngrăşămintelor. Ed. Ceres, Bucureşti

Davis, J. C.-Parker, M. S. (1993): Zinc toxicity symptom development and partitionong of biomass and zinc in peanut plants. J. Plant. Nutr., 16. 12. 2353-2369.

Epstein, E. (1972): Mineral Nutrition of Plants. Principles and Perspectives. Wiley and Sons, Inc., New York-LondonSydney

Farago, M. E. (1994): Interaction between elements. Physiol., In: (Farago, M. E. ed.) Plants and the chemical elements. VCH, Weinheim, New York, Basel, Cambridge, Tokyo, 23-41.

Holb, I. J.-Heijne, B. (2001): Evaluating primary scab control in organic apple production. Gartenbauwissenschaft-Eur. J. Hort. Sci., 66. 5. 254-261. 
Holb, I. J.-Jong, de P. F.-Heijne, B. (2003): Efficacy and phytotoxicity of lime sulphur in organic apple production. Ann. Appl. Biol., 142. 2. 225-233.

Kahle, H. (1993): Response of roots of trees to heavy metals. Environ. Exp. Bot., 33. 99-119.

Lanaras, T.-Moustakas, M.-Symeonidis, L.-Diamantoglou, S.Karataglis, S. (1993): Plant metal content, growth responses and some photosynthetic measurements on field-cultivated wheat growing on ore bodies enriched in $\mathrm{Cu}$. Physiol. Plant., 88. 307-314.

Mehra, A.-Farago, M. E. (1994): Metal Ions and Plant Nutrition. In: Plants and Chemical Elements, 31-67. Edited by Farago, M. E., VCH, Weinheim, New York, Basel, Cambridge, Tokyo

Menkel, K.-Kirkby, E. A. (1994): Principles of plant nutrition. Int. Potash., Bremen, 537-539.

Merrington, G.-Rogers, S. L.-Van Zwieten, L. (2002): The potential impact of long-term copper fungicide usage on soil microbial biomass and microbial activity in an avocado orchard. Austral. J. Soil Res., 40. 5. 749-759.

Mohr, H.-Schopfer, P. (1995): Plant Physiology. Springer-Verlag, Berlin, Heidelberg

Ouzounidou, G. (1994): Copper induced changes on growth, metal content and photosynthetic function of Alysum montaneum L. plants. Environ. Exp. Bot., 34. 2. 165-172.

Ouzounidou, G. (1995a): Cu-ions mediated changes in growth, chlorophyll and other ion content in a Cu-tolerant Koeleria splendens. Biol. Plant., 37. 1. 71-78.

Ouzounidou, G. (1995b): Effect of copper on germination and seedling growth of Minurtia, Alyssum and Thlasppi. Biol. Plant., 37. 3. 411-416.

Punz, W. F.-Siegardt, H. (1993): The response of roots of herbaceus plant species to metals. Environ. Exp. Bot., 33. 1. 85-98.

Ross, S. M. (1994): Sourcess and forms of potentially toxic metals in soil-plant system. (In: Wilez, J. and Aons, eds.), Toxic metals in soil-plant system. Chochester, New York, Brisbane, Toronto, Singapore, 5-31.

Salisbury, F. B.-Ross, C. W. (1992): Plant physiology. Wadsworth Publishing Company, Inc. Belmont

Scharrer, K. (1975): Biochemie der Spurenelelemente. Paul Parey, Berlin
Stover, E.-Hebb, J.-Sonoda, R.-Salyani, M. (2004): Airblast application of copper fungicide to grapefruit does not affect windscar. Hortscience, 516-519.

Sutcliffe, J. C.-Baker, D. A. (1974): Plants and Mineral Salts. Edward Arnold, London

Taiz, L.-Zeiger, E. (1991): Plant Physiology. The Benjamin/Cummings Publishing Company, Inc., Redwood City

Tomulescu, I. M.-Burcă, S. (2003a): Efectul cadmiului asupra germinației şi cantităţii de acizi nucleici la fasole. Analele Protecția Mediului, Oradea, 217-226.

Tomulescu, I. M.-Burcă, S. (2003b): Influența microelementului cupru asupra cantităţii de acizi nucleici şi a dimensiunii medii a nucleilor la Zea mays, hibrid Kiskun SC 297. Analele Protecția Mediului, Oradea, 227-234.

Tomulescu, I. M.-Molnar, S.-Burcă, S.-Covaciu-Marcov, S. D. (2000a): Influența minereului de uraniu asupra cantității de acizi nucleici la speciile de licheni Cladonia rangiformis, Cladonia cornuta şi Cladonia fimbriata. Analele Universităţii din Oradea, Fasc. Biologie, VII. 199-212.

Tomulescu, I. M.-Molnar, S.-Burcă, S.-Covaciu-Marcov, S. D. (2000b): Influența radioactivității asupra cantității de acizi nucleici la speciile Cladonia fimbriata, Cladonia cornuta, Cladonia fimbriata, Plantago lanceolata, Plantago major, Typha angustifolia. Materialele Conferinței ŞtiințificoMetodice, II. Chişinău, 9-10 octombrie, 46-49.

Tomulescu, I. M.-Radoviciu, E. M.-Merca, V. (2003a): Efectele unor microelemente $(\mathrm{CD}, \mathrm{CR})$ asupra germinației şi a variaţiei cantităţii de acizi nucleici la fasole. Buletinul Societății Naționale de Biologie Celulară, 226. (volum abstracte)

Tomulescu, I. M.-Radoviciu, E. M.-Merca, V. (2003b): Influența microelementelor cupru şi zinc asupra germinației şi a dimensiunii medii a nucleilor la Zea mays (Hibrid Kiskun SC 297). Buletinul Societății Naționale de Biologie Celulară, 230. (volum abstracte)

Trifu, M. (1976): Nutriția minerală a plantelor. Facultatea de Biologie, Geografie şi Geologie, uz intern, Cluj-Napoca

Trifu, M.-Bărbat, I. (1997): Fiziologia plantelor. Capitole alese, Ed. Viitorul Românesc, Bucureşti

Vangrosveldt, J.-Clijsters, H. (1994): Toxic Effects of Metals. In: Plants and Chemical Elements, 150-177. Edited by Farago, M. E., VCH, Weinheim, New York, Basel, Cambridge, Tokyo 